\title{
PHYSICO-CHEMICAL AND BACTERIOLOGICAL COMPOSITION IN A METROPOLITAN DRINKING WATER DISTRIBUTION SYSTEM IN KATHMANDU
}

Pratima Tamrakar, Suman K. Shakya, and Chitra B. Baniya

Journal of Institute of Science and Technology

Volume 22, Issue 1, July 2017

ISSN: 2469-9062 (print), 2467-9240 (e)

Editors:

Prof. Dr. Kumar Sapkota

Prof. Dr. Armila Rajbhandari

Assoc. Prof. Dr. Gopi Chandra Kaphle

JIST, 22 (1): 159-164 (2017)

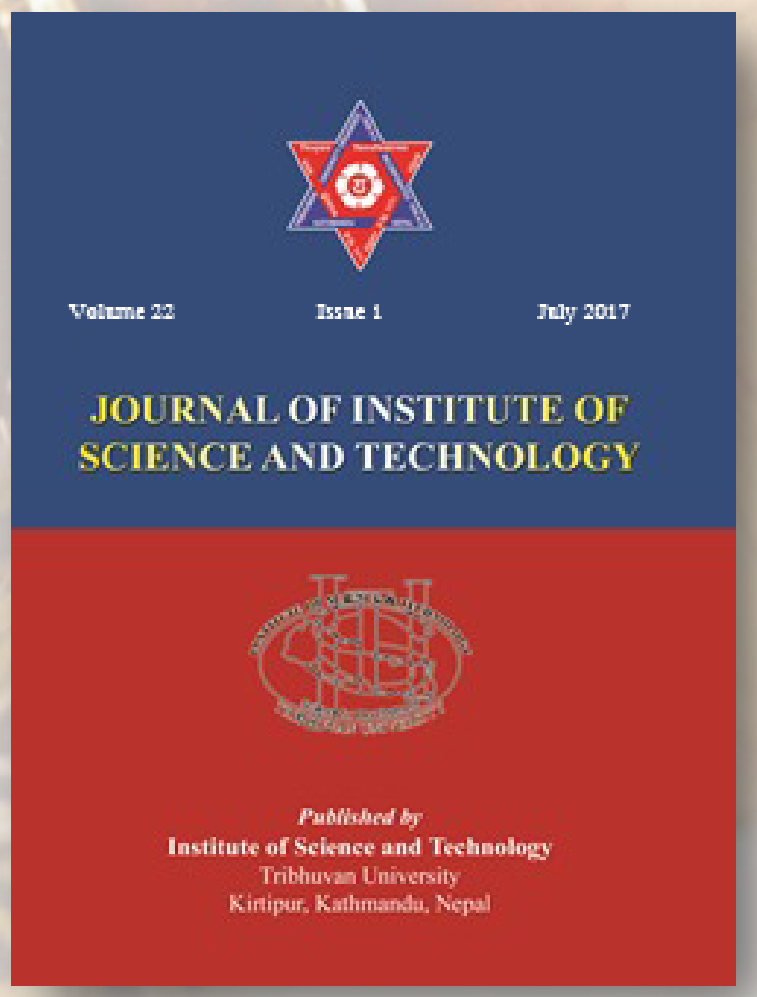

Published by:

Institute of Science and Technology

Tribhuvan University

Kirtipur, Kathmandu, Nepal 


\title{
PHYSICO-CHEMICAL AND BACTERIOLOGICAL COMPOSITION IN A METROPOLITAN DRINKING WATER DISTRIBUTION SYSTEM IN KATHMANDU
}

\author{
Pratima Tamrakar $^{1, *}$, Suman K. Shakya ${ }^{2}$, and Chitra B. Baniya ${ }^{3}$ \\ ${ }^{1}$ Central Department of Zoology, Tribhuvan University, Kathmandu, Nepal, \\ ${ }^{2}$ School of Environmental Science and Management, Pokhara University, Kathmandu, Nepal, \\ ${ }^{3}$ Central Department of Botany, Tribhuvan University, Kirtipur, Kathmandu, Nepal \\ Corresponding E-mail: tamrakarpr@gmail.com
}

\begin{abstract}
The study was concentrated on water quality appraisal in metropolitan drinking water distribution system in Kathmandu during 2011 to 2015 AD. The study covers 24 research areas from surface water sources, treatment plants, processing and water supply networks of public, private and community drinking water suppliers in the main city of Kathmandu valley. Water quality was analyzed under six physical, seventeen chemical and two bacteriological parameters. All tests were conducted in accordance with the procedures laid down in the Standard Methods. Total 320 samples collected during two years of periods. The physicochemical parameters of tested water samples from sources, reservoirs and taps were found to be within the range of National Drinking Water Quality Standard (NDWQS). The turbidity and $\mathrm{pH}$ values for most of the tested water samples from sources, reservoirs and taps except for a few source and tap samples were found to be within the NDWQS guideline values. The chemical parameters values of majority of tested source water samples were below the maximum level. The values of iron, manganese, sodium and chloride content of some source samples were found higher than the maximum permissible level recommended by NDWQS and WHO guideline. Bacteriologically, larger proportion of water samples (sources, reservoirs and taps) were found to be unacceptable. The present study disclosed fecal contamination to be the major problem in drinking water from source to the distribution for city water supply systems in selected metropolitan areas. The physico-chemical qualities of water in most cases were within acceptable limit.
\end{abstract}

Keywords: Bacteriological contamination, Physico-chemical characteristics, Water quality, Water treatment, Water borne diseases.

\section{INTRODUCTION}

Consumption of water contaminated with hazardous chemicals or pathogenic microorganisms possess serious health threat or various waterborne diseases. It is estimated that about $80 \%$ of all sickness and disease in the world is caused by inadequate sanitation, polluted water or unavailability of water (WHO, 1986). The health burden linked to inadequate and unsafe water, poor sanitation and hygiene is highest among underprivileged people.

In Nepal, there are frequent reports of unacceptable water supply, particularly faecal or bacterial contamination in drinking water, including in piped supply systems. Although the vital role of clean and safe water in maintaining good health has been recognized, the quality of drinking water has often been neglected in developing countries, including Nepal.

The drinking water quality of Kathmandu metropolitan area has been degraded physically, chemically and microbiologically. The drinking water sources of stone spouts, taps and tube wells are contaminated with fecal coliform and $\mathrm{pH}$, ammonia, turbidity, electrical conductivity and arsenic which are deviated from the WHO guidelines and Nepal standard for drinking water. Enteric bacteria are found in biofilm in drinking water distribution system of Kathmandu valley (Shakya et al., 2008). Bacteriological investigation on quality of processed drinking water in Kathmandu is contaminated with fecal pollution. Inadequate Free residual Chlorine (FRC) in various distribution points and presence of fecal contamination in most of places are major causes 
of spread of water borne diseases in Kathmandu every summer.

\section{MATERIALS AND METHODS}

Identification of sampling sites, water sampling, water quality parameters and testing were done following the prescribed standard methods (APHA, 1995). The study areas were from water source of Sundarijal to Mahakalchor, Kapan, Chabahil, Sukedhara, Gaurighat, Mitrapark, Sinamangal, Anamnagar, New Road, Dhumbarahi, Boudha, Gaushala, Baneshwor and Ghattekulo drinking water supply points. Altogether 32 sample sites were selected from the study areas at the ratio of 1 sample per 5000 populations. Samples were taken from Sundarijal intake, treatment plants, deep wells, supplied tap stand of house connections, processed water, stone spout, community-well and private shallow tube wells.

Total 320 samples were collected during summer seasons only because of low water discharge in the water sources during March-April. Two samples from each sampling sites were collected for physico-chemical and bacteriological test. For physico-chemical analyses, water samples were collected in 1 liter polyethylene bottles. The temperature, appearance, taste and odor and total chlorine was tested immediately at sampling sites. For bacteriological analyses, sterilized bottles of 0.5 liter capacity were used and two drops of $\mathrm{Na}_{2} \mathrm{~S}_{2} \mathrm{O}_{3}$ was added in every sample for preserving bacteria. Total coliform and fecal coliform were detected in laboratory by standard MPN method. Rest of 19 parameters i.e. Turbidity, Electrical Conductivity, pH, Alkalinity, Total Hardness, Calcium Hardness, Calcium ion, Magnesium Hardness, Magnesium ion, Iron, Manganese, Total Ammonia, Sodium, Potassium, Fluoride, Arsenic, Aluminum, Chloride, Total Chlorine were tested by following the standard methods of APHA (1995) within 12 hours of samples collection.

For sampling from water distribution system, only unrusted direct service pipeline water supply taps were selected. The sample was not taken from leakage in between spindle and gland as well as the pipe linked with storage tank or reservoir and upper tanks. The tap water was collected after opening and letting water flow for 2-3 minutes to get true representative samples of source and distribution system.

Altogether 153 households within the study areas were selected for in-depth interviewed and 10 focus groups discussion with the water managers were conducted to get information about their knowledge on water quality and practices adopted in its treatment. Altogether 25 water vendors and suppliers were interviewed. Research was conducted in 8 public 120 private schools and reviewed their course curriculum on water quality assessment. Interview was conducted with 28 teachers of environment, population, health and science as well as students of the same schools. Observation was made on the water quality management in the school and practical use of drinking water by the students.

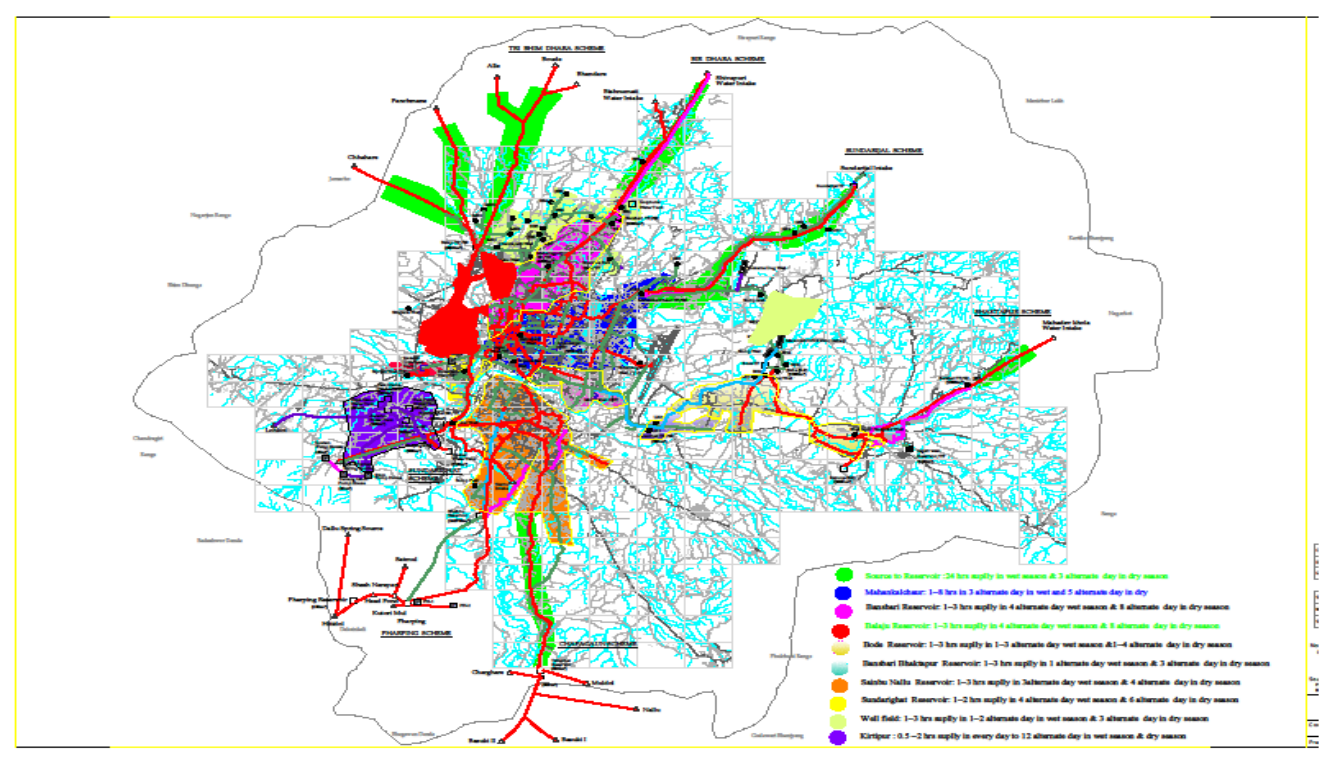

Fig. 1. Study Area and the location of the sampling points. 


\section{RESULTS AND DISCUSSION \\ Water Quality Analysis \\ Physical Parameters}

The summary of statistical data of physical water quality parameters is presented in table 1 .

The average temperature of all sites ranged from $20.0^{\circ} \mathrm{C}$ to $26.0^{\circ} \mathrm{C}$. The average value of color was 5.1 to 5.9 o Hazen. The processed water has no taste and odor. The appearance of surface water, treatment plants and their supplies to house connections, processed water, stone spouts appeared clear. The water of deep wells and their supplies to house connections were either clear or Hazy state. The average value of turbidity in all the sampling sites was 9.9 NTU which was slightly higher than NDWQS guide line value of 5 NTU.
The $\mathrm{pH}$ values were less than threshold level in Shankha park deep well and its supplies for Sukedhara and stone spouts, private well and tube well. The mean $\mathrm{pH}$ values ranged from 6.7 to 6.9 in surface water, treatment plants and their supplies to house connections and deep well and their supplies water were ranged between 6.2 and $7.4 \mathrm{pH}$ values and the processed water ranged from 6.9 to 7.1 . These values were within the NDWQS and WHO guideline value of 6.5 to 8.5 .

The Sundarijal treatment plants and their water supply system shows low conductivity (less than 40 $\mu \mathrm{S} / \mathrm{cm})$. The mean value of community shallow well and private tube well ranged between 150 $\mu \mathrm{S} / \mathrm{cm}$ and $860 \mu \mathrm{S} / \mathrm{cm}$, which was higher compared to others. However, all the values are within the NDWQS and WHO ( $\approx 1500 \mu \mathrm{S} / \mathrm{cm})$.

Table 1. Summary of statistical data of physical water quality parameters.

\begin{tabular}{|c|c|c|c|c|c|c|c|c|c|c|c|c|c|}
\hline \multirow{2}{*}{ Variables } & \multirow{2}{*}{ Unit } & \multicolumn{6}{|c|}{2011} & \multicolumn{6}{|c|}{2012} \\
\hline & & Mean & Med & Min & Max & Std & $\mathrm{Cv}$ & Mean & Med & Min & Max & Std & $\mathrm{Cv}$ \\
\hline Temperature & ${ }^{0} \mathrm{C}$ & 23 & 23 & 20 & 25 & 1 & 6 & 22 & 22 & 18 & 26 & 2 & 9 \\
\hline $\mathrm{pH}$ & & 6.9 & 7.0 & 6.2 & 7.4 & 0.3 & 4.8 & 6.7 & 7.0 & 0.0 & 7.6 & 1.3 & 19.3 \\
\hline $\begin{array}{l}\text { Electrical } \\
\text { Conductivity }\end{array}$ & $\mu \mathrm{S} / \mathrm{cm}$ & 213 & 97 & 12 & 800 & 215 & 101 & 229 & 110 & 12 & 860 & 239 & 104 \\
\hline Turbidity & NTU & 10 & 5 & 1 & 45 & 12 & 122 & 10 & 4 & 1 & 50 & 13 & 129 \\
\hline Color & ${ }^{\circ}$ Hazen & 6 & 2 & 1 & 25 & 7 & 123 & 5 & 2 & 1 & 20 & 6 & 111 \\
\hline
\end{tabular}

\section{Chemical Parameter}

The summary of statistical data of chemical water quality parameters are presented in table 2 .

Sinamangaldeep well and Ramhiti deep well and their supplies to house connections have maximum alkalinity value of $206 \mathrm{mg} / \mathrm{L}$ and $220 \mathrm{mg} / \mathrm{L}$ respectively. The averages of all mean values of samples were $79.88 \mathrm{mg} / \mathrm{L}$. This is within the standard of NDWQS and WHO.

None of the sampling research points had exceeded the limit in Kapan and the maximum hardness in tube well water was found to be $300 \mathrm{mg} / \mathrm{L}$. The treatment plants, water supply system and processed water of Sundarijal surface water source had lower hardness than deep wells, well, tube well and stone spouts. The average value of all the sampling sites was $78.57 \mathrm{mg} / \mathrm{L}$.

The average value of iron and manganese of all the sampling sites were $0.92 \mathrm{mg} / \mathrm{L}$ and $0.08 \mathrm{mg} / \mathrm{L}$ respectively. This is within the standard of
NDWQS and WHO guideline value of 0.3 and 0.2 $\mathrm{mg} / \mathrm{L}$ respectively.

However from the study it was found that ammonia of house connection from Ramhiti deep well is about $65 \mathrm{mg} / \mathrm{L}$, which is likely higher levels of ammonia in sources, due to pollution. Ammonia can be present in high levels in wells because of underlying geochemistry (peat and lignite) (APHA, 2000).

Similarly, the mean value of total ammonia in surface water, treatment plants and their supplies ranged between $0.02 \mathrm{mg} / \mathrm{L}$ and $0.8 \mathrm{mg} / \mathrm{L}$; deep wells, and their supplies to house connections was within $7 \mathrm{mg} / \mathrm{L}$ to $65 \mathrm{mg} / \mathrm{L}$; community well and private tube wells within $0.2 \mathrm{mg} / \mathrm{L}$ to $52 \mathrm{mg} / \mathrm{L}$; stone spouts ranged between $0.02 \mathrm{mg} / \mathrm{L}$ and processed water was recorded as $0.02 \mathrm{mg} / \mathrm{L}$. Ammonia in processed water was very low because of reverse osmosis process of water. The average value of ammonia in all the sampling sites was 9 
$\mathrm{mg} / \mathrm{L}$. This exceeded the standard of NDWQS and WHO of $1.5 \mathrm{mg} / \mathrm{L}$.

The mean value of sodium $(\mathrm{Na}+)$ in surface water, treatment plants and their supplies ranged between $1 \mathrm{mg} / \mathrm{L}$ and $2 \mathrm{mg} / \mathrm{L}$; deep wells, and their supplies to house connections was found within $1.5 \mathrm{mg} / \mathrm{L}$ to $65 \mathrm{mg} / \mathrm{L}$; community well and private tube wells fell within $4 \mathrm{mg} / \mathrm{L}$ to $40 \mathrm{mg} / \mathrm{L}$; stone spouts ranged between 1 to $8 \mathrm{mg} / \mathrm{L}$ and processed water recorded $1 \mathrm{mg} / \mathrm{L}$. Ammonia in processed water was very low because of reverse osmosis process of water. The average value of Sodium $(\mathrm{Na}+)$ of all the sampling sites was $12.94 \mathrm{mg} / \mathrm{L}$.

Table 2. Summary of statistical data of chemical water quality parameters.

\begin{tabular}{|c|c|c|c|c|c|c|c|c|c|c|c|c|c|}
\hline \multirow[t]{2}{*}{ Variables } & \multirow[t]{2}{*}{ Unit } & \multicolumn{6}{|c|}{2011} & \multicolumn{6}{|c|}{2012} \\
\hline & & Mean & Med & Min & Max & Std & $\mathrm{Cv}$ & Iean & Med & Min & Max & Std & $\mathrm{Cv}$ \\
\hline Alk & $\mathrm{Mg} / \mathrm{L}$ & 74.88 & 35.00 & 6.00 & 220.00 & 73.88 & 98.67 & 4.88 & 31.00 & 4.00 & 220.00 & 82.14 & 96.78 \\
\hline Total & L & 9 & 42.00 & 4.00 & 0 & 42 & 63 & 4 & 3.00 & 4.00 & 296.00 & 90.54 & 0.50 \\
\hline Calc & $\mathrm{Mg} / \mathrm{L}$ & 52.00 & 26.50 & 2.00 & 240.00 & 59.71 & 114.84 & 55.31 & 22.00 & 2.00 & 230.00 & 65.30 & 118.06 \\
\hline agnin & $\mathrm{Mg} / \mathrm{L}$ & 23.19 & 15.50 & 2.00 & 66.00 & 21.45 & 92.51 & 6.56 & 14.00 & 2.00 & 94.00 & 27.36 & 102.99 \\
\hline Calci & $\mathrm{Mg} / \mathrm{L}$ & 20.80 & 10.60 & 0.80 & 96.00 & 23.89 & 114.84 & 22.16 & 8.80 & 0.80 & 92.12 & 26.12 & 117.88 \\
\hline Magn & $\mathrm{Mg} / \mathrm{L}$ & 5.61 & 3.74 & 0.48 & 16.03 & 5.21 & 92.80 & 6.44 & 3.40 & 0.48 & 22.80 & 6.64 & 103.11 \\
\hline on & $\mathrm{L}$ & 0 & 0.20 & 0.01 & 5.00 & 32 & 31 & 93 & 0.10 & 0.01 & 5.00 & .32 & 2.64 \\
\hline Man & $\mathrm{Mg} / \mathrm{L}$ & 0.08 & 0.02 & 0.00 & 0.48 & 0.12 & 148.27 & 0.08 & 0.01 & 0.00 & 0.50 & 0.12 & 143.89 \\
\hline 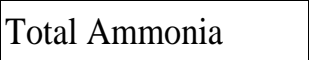 & $\mathrm{Mg} / \mathrm{L}$ & 861 & 0.22 & 0.02 & 65.00 & 15.84 & 183.37 & 9.36 & 0.16 & 0.02 & 56.00 & 16.87 & 180.24 \\
\hline sodium & $\mathrm{Mg} / \mathrm{L}$ & 70 & 2.00 & 1.00 & .00 & 53 & 138.06 & .19 & 00 & 1.00 & 5.00 & 18.23 & 38.27 \\
\hline Potas & $\mathrm{Mg} / \mathrm{L}$ & 4.74 & 0.25 & 0.00 & 40.00 & 9.15 & 193.14 & 4.39 & 0.00 & 0.00 & 40.00 & 8.54 & 194.55 \\
\hline & 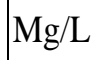 & 0.20 & 0.00 & 0.00 & 2.00 & 0.56 & 283.39 & 0.19 & 0.0 & 0.00 & 2. & 0. & 282.14 \\
\hline Arsenic & $\mathrm{Mg} / \mathrm{L}$ & 0.00 & 0.00 & 0.00 & 0.01 & 0.00 & 230.88 & 0.00 & 0.00 & 0.00 & 0.01 & 0.00 & 207.44 \\
\hline Alum & $\mathrm{Mg} / \mathrm{L}$ & 0.14 & 0.00 & 0.00 & 1.00 & 0.25 & | & 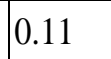 & 0.00 & 0.00 & 0.50 & 0.21 & 189.98 \\
\hline $\mathrm{Tc}$ & $g / L$ & 16.53 & 7.68 & 1.90 & 120.00 & 23.80 & 144.03 & 22.01 & 7.68 & 1.92 & 130.00 & 35.37 & 160.72 \\
\hline Total Chlorine & $\mathrm{Mg} / \mathrm{L}$ & 0.05 & 0.00 & 0.00 & 0.50 & 0.13 & 252.19 & 0.10 & 0.00 & 0.00 & 1.20 & 0.25 & 243.19 \\
\hline
\end{tabular}

Most of deep wells, well, stone spout and tube well water had detected the potassium, whereas maximum found at Sinamangal deep well was 40 $\mathrm{mg} / \mathrm{L}$. Surface water, Treatment plants and their supplies to house connections water samples had detected very low potassium.

It was found that all research points except Sinamangal well water $2 \mathrm{mg} / \mathrm{L}$ was within the upper limit of $1.5 \mathrm{mg} / \mathrm{L}$ guideline value. Fluoride $(\mathrm{Fl})$ content in water was not detected in the study.

The mean value of arsenic detected in Sinamangal well, treatment plant, tap water was $0.01 \mathrm{mg} / \mathrm{L}$, well and private tube wells was $0.001 \mathrm{mg} / \mathrm{L}$ and deep wells, and their supplies to house connections as $0.01 \mathrm{mg} / \mathrm{L}$. Other research points such as surface water, treatment plants and their supplies, stone spouts and processed water were found arsenic free. A similar finding was reported by Shakya et al. (2012).

Aluminum was not detected in deep wells, and their supplies to house connections, community well and private tube wells and processed water. The average value of aluminum of all the sampling sites was $0.46 \mathrm{mg} / \mathrm{L}$.

The average value of Chloride $(\mathrm{Cl})$ of all the sampling sites was $19.27 \mathrm{mg} / \mathrm{L}$. Similarly, the average value of Chlorine $\left(\mathrm{Cl}_{2}\right)$ of all the sampling sites was $0.34 \mathrm{mg} / \mathrm{L}$.

\section{Bacteriological Parameter}

The summary of statistical data of bacteriological water quality parameters are presented in table 3 . 
Table 3. Summary of statistical data of bacteriological water quality parameters.

\begin{tabular}{|l|l|l|l|l|l|l|l|}
\hline \multirow{2}{*}{ Variables } & \multirow{2}{*}{ Unit } & \multicolumn{5}{|c|}{ Average value of all sampling stations during two phases } \\
\cline { 3 - 8 } & & Mean & \multicolumn{1}{|c|}{ Med } & \multicolumn{1}{c|}{ Min } & \multicolumn{1}{c|}{ Max } & \multicolumn{1}{c|}{ Std } & \multicolumn{1}{c|}{ Cv } \\
\hline Total Coliform & MPN & 37.59 & 5.5 & 5 & $>180$ & 66.85 & 177.8 \\
\hline Fecal Coliform & MPN & 1 & 0 & 0 & 6 & 1.65 & 292.95 \\
\hline
\end{tabular}

The study had detected that about $33 \%$ of sampling stations were found safe, $30 \%$ were low, $18.5 \%$ were intermediate risk and $8.5 \%$ have high risk (>100 coliform $/ 100 \mathrm{ml}$ ) according to WHO guideline on bacteriological classification. The clear water of Mahankalchor treatment plant, Anamnagar, Kamalachi house connections and raw water of Ramhiti, Shankhapark, Sinamangal deep wells were found to be safe. Other sampling stations were contaminated with total coliform. Pant, (2010) revealed the coliform 267, 129, 148 CFU/100ml in shallow well, tube well, deep well respectively in the Kathmandu which is the similar with the present investigation. The maximum fecal coliform was recorded in Sukedhara stone spout 7 MPN/100ml and deep well supplies to Sukedhara house connections (7 MPN//100ml).

\section{Principal Component Analysis of Water Quality Variables}

The principal component analysis (PCA) of all measured water quality variables done in $R$ environment ( $\mathrm{R}$ Core Team, 2016) through vegan package (Oksanen et al., 2017) resulted 43\% variation by the first axis and $17 \%$ variation by its second axis (Figure 2).

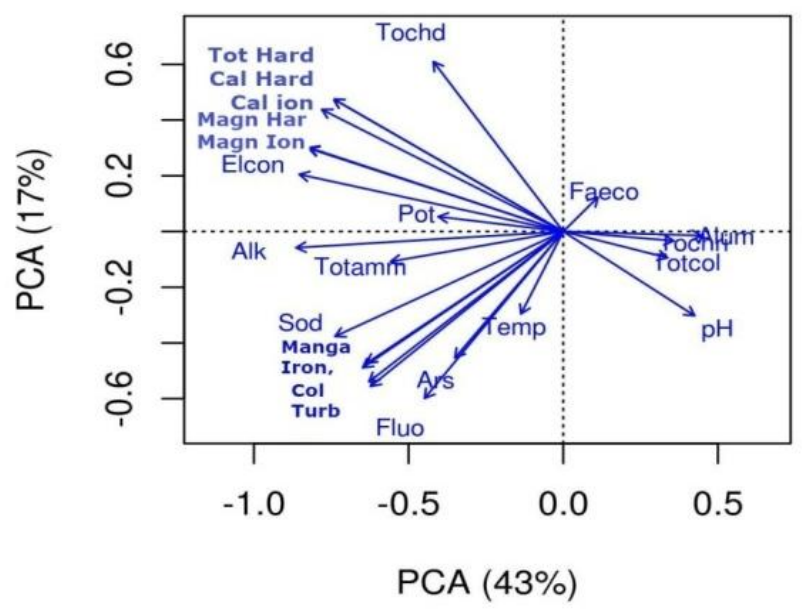

Fig. 2. Principal component analysis of water quality variable in 2011.

Correlation among water quality variables through this PCA showed a cleared pattern to each other. The total chlorides (Tochd), total hardness (Tothar), calcium hardness (Calhar), calcium ion (Caion), magnesium hardness (Magha), Magnesium ion (Magion), electronic conductivity (Elcon), and potassium (Pot) all these eight variables showed significant positive correlation among each other. The value of $\mathrm{pH}$ has significance negative correlation with turbidity $(\mathrm{P}=0.015)$, hardness $(\mathrm{P}=0.008)$, calcium $(\mathrm{P}=0.010)$, magnesium $(\mathrm{P}=0.009)$, calcium ion $(\mathrm{P}=0.019)$, magnesium ion $(\mathrm{P}=0.019)$, potassium $(\mathrm{P}=0.000)$, chloride $(\mathrm{P}=0.012)$, coliform $(\mathrm{P}=0.031)$, significance positive correlation with aluminum $(\mathrm{P}=0.008)$. Likewise, The Fecal Coliform has closed significance negative correlation with temperature $(\mathrm{P}=0.035)$ in first phase.

The principal component analysis (PCA) of all measured water quality variables done in $R$ environment ( $\mathrm{R}$ Core Team 2016) through vegan package (Oksanen et al., 2017) resulted 43\% variation by the first axis and $20 \%$ variation by its second axis (Figure 3).

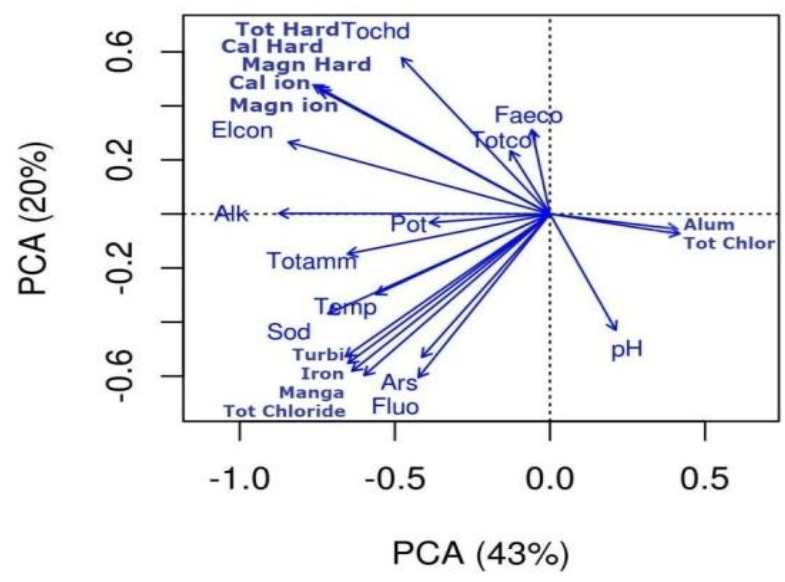

Fig. 3. Principal component analysis of water quality variables in 2012.

In 2012, Correlation among water quality variables through this PCA showed a clear pattern to each other. The total chlorides (Tochd), total hardness (Tothar), calcium hardness (Calhar), calcium ion (Caion), magnesium hardness (Magha), Magnesium ion (Magion), electronic conductivity (Elcon), and potassium (Pot), Faecal coliform (Faeco), Total coliform (Totcol)) all these ten variables showed significant positive correlation among each other. 
The $\mathrm{pH}$ showed the significance negative correlation with EC $(\mathrm{P}=0.000)$, alkalinity $(\mathrm{P}=0.02)$, hardness $(\mathrm{P}=0.001)$, calcium $(\mathrm{P}=0.002)$, calcium ion $(\mathrm{P}=0.002)$, magnesium $(\mathrm{P}=0.000)$, magnesium ion $(\mathrm{P}=0.000)$, potassium $(\mathrm{P}=0.023)$, chloride $(\mathrm{P}=0.002)$. Likewise, the fecal coliform has significance negative correlation with temperature $(\mathrm{P}=0.043), \mathrm{pH}(\mathrm{P}=0.002)$, coliform $(\mathrm{P}=0.035)$ in second phase. In the both phases, the fecal coliform has significance $(\mathrm{P}=0.002)$ negative correlation with temperature, $\mathrm{pH}$, and coliform.

\section{CONCLUSION}

The quality of water sources are found relatively better than pipeline supplied to consumers, this is because of coliform and fecal coliform found in various samples of research sites. Surface water is better than deep well and shallow wells, tube wells because the fluorides, manganese, ammonia, iron, color, turbidity were recorded above the tolerance level of NDWQS, WHO guideline and bitter taste in some research points. The average value of ammonia of all the sampling sites is $9 \mathrm{mg} / \mathrm{L}$ and chloride value of $130 \mathrm{mg} / \mathrm{L}$ some sampling sites indicates sewage pollution in water samples. Processed water was demineralized with reverse osmosis process and lack of quantity of essential minerals and also coliform were found. Stone spout water has also maximum density of coliform, fecal coliform, and aluminum, magnesium, which was exceeding the tolerance limit of NDWQS, WHO guideline and high risk for consumption.

The people in the Kathmandu valley is facing with Sevier scarcity of water and coping with alternative water source of available quality of water. People are much depended on suppliers (KUKL and water vendors) for water quality because water quality Knowledge level of community is very inadequate. There is no course and curriculum on water quality management was found in school. Water lab test and water quality knowledge of supplier and consumers was found to be limited. Community is adopting traditional water management and cleans the water source. They are still practicing traditional methods of water purification and water treatment techniques due to limited of knowledge on water quality and its management. Thus, the waterborne diseases are breaking up every year.

\section{REFERENCES}

APHA (1995). Standard Methods for the Examination of Water and Waste Water, 19th edition, American Public Health Association, Washington, D.C.

APHA, AWWA, WPCF (2000). Standard Method for the Examination of Water and Wastewater. $20^{\text {th }}$ edition. American Health Association, Washington DC, USA.

CBS (2011). Statistical Year Book of Nepal, Central Bureau of Statistics, Katmandu, Nepal.

CEMAT (2000). Report on Surface Water Quality Monitoring Works of Kathmandu Valley, Urban Water Supply Reforms in the Kathmandu Valley Project, Kathmandu.

Collins, R. and Jenkins, A. (1996). The impact of agricultural land use on stream chemistry in the Middle Hills of the Himalayas, Nepal. $J$ Hydrol, 185 (1): 71-86(16).

Kurosawa, K.; Uddin, M. S.; Yiping, X.; Tani, M. and Shakya, S. K. (2013). Arsenic concentration and related water quality parameters of well water in the Terai Plain of Nepal. Japan Arsenic Symposium Miyazaki, Japan November, 2013.

Oksanen, J.; Blanchet, F. G.; Friendly, M.; Kindt, R.; Legendre, P.; McGlinn, D. et al. (2017).

Pant, B. R. (2010). Ground water quality in Kathmandu valley of Nepal. Environ Monit Assess, DOI 10.1007/S10661-010-1706-y.

$\mathrm{R}$ Core Team (2016). R: A language and environment for statistical computing.

R Foundation for Statistical Computing, Vienna, Austria. URL: https://www.R-project.org/.

Shakya, S. K. et al. (2008). Bacteriological Risk Analysis of Rural Water Supply Schemes in Western Development Region of Nepal, Journal of Food Science and Technology Nepal (JFSTN), 3: 123-125.

Shakya, S. K. and Maharjan, M. (2012). Local capacity building for sustainable arsenic mitigation in lowland, Nepal. Proceedings of the "18th Japan Arsenic Symposium" held in Miyazaki, Japan 24-25 November, 2012.

UNICEF, http://www.unicef.org/media/media_ 21423.htm

Vegan: Community Ecology Package. R package version 2.4-2.https://CRAN.R-project.org/ package $=$ vegan

WHO, 2008. Guidelines for Drinking Water Quality. 3rd Edition, World Health Organization, Geneva.

WHO, 2012.http://www.who.int/water_sanitation _health/dwq/fulltext.pdf 